\title{
Application of regenerative medicine in treatment of acne scars
}

\author{
Mauro Barone ${ }^{1}$, Stefania Tenna ${ }^{1}$, Annalisa Cogliandro ${ }^{1}$, Vincenzo Panasiti ${ }^{1}$, Carolina \\ Nobile ${ }^{2}$, Paolo Persichetti ${ }^{1}$
}

${ }^{1}$ Department of Plastic Reconstructive and Aesthetic Surgery, Campus Bio-Medico University of Rome, 00128 Roma, Italy. ${ }^{2}$ Department of Ematology, Campus Bio-Medico University of Rome, 00128 Roma, Italy.

Address for correspondence: Dr. Mauro Barone, Department of Plastic Reconstructive and Aesthetic Surgery, Campus Bio-Medico University of Rome, Via Alvaro del Portillo, 21, 00128 Roma, Italy. E-mail: maurosabbarone@gmail.com

\begin{abstract}
Aim: The aim of this study is to evaluate the efficacy of the protocol of nanofat and platelet-rich plasma (PRP) infiltration and fractional $\mathrm{CO}_{2}$ laser resurfacing for face atrophic scars by acne and to analyse patient's satisfaction with the original questionnaire. Methods: From March 2014 to June 2015, 30 patients with acne scarsonthe cheeks were selected for this pilot study. Patients were evaluated pre- and postoperatively by a physical examination, photographs and ultrasound scan with a $22 \mathrm{MHz}$ probe to measure subcutaneous tissue thickness. All patients were treated by infiltration of nanofat and PRP. The production of PRP was achieved by RegenLab THT tube ${ }^{\circledast}$ method. Subsequently, patients were randomly divided into two groups: group $\mathrm{A}$, which also underwent a fractional $\mathrm{CO}_{2}$ laser resurfacing at $15 \mathrm{~W}$; and group $\mathrm{B}$, which only underwent nanofat and PRP infiltration. The original questionnaire of quality of life questionnaire (QoL-Q) was also administered pre- and postoperatively to analyse satisfaction and aesthetical perception of the result. Results: Preoperative thickness of subcutaneous tissue of patients from group A was $0.532 \mathrm{~mm}$, whilst preoperative thickness of subcutaneous tissue of patients from group B was $0.737 \mathrm{~mm}$. Postoperative thickness of subcutaneous tissue was $1.201 \mathrm{~mm}$ in group A and $1.367 \mathrm{~mm}$ in group B. The improvement of thickness of subcutaneous tissue was $0.668 \mathrm{~mm}$ in group A and $0.630 \mathrm{~mm}$ in group B. The authors applied a $t$-test on unpaired data, comparing the difference in thickness obtained with the treatment both in group A and in group B, with a $P=0.7289$ (not significant). All patients in both groups had a treatment benefit. Conclusion: Combined approach with nanofat, $\mathrm{PRP}$ and $\mathrm{CO}_{2}$ laser seems to be effective to improve trophic scars, however, infiltration alone proved to significantly increase skin and subcutaneous tissue thickness. QoL-Q confirmed the impact of acne scars on the face in social life and relationships.
\end{abstract}

Key words:

Acne; scars; regenerative; laser; nano-fat

\begin{tabular}{|l|l|}
\hline \multicolumn{2}{|c|}{ Access this article online } \\
\hline Quick Response Code: & Website: \\
\hline & http://www.parjournal.net \\
\cline { 2 - 3 } & \\
\hline
\end{tabular}

This is an open access article distributed under the terms of the Creative Commons Attribution-NonCommercial-ShareAlike 3.0 License, which allows others to remix, tweak and build upon the work non-commercially, as long as the author is credited and the new creations are licensed under the identical terms.

For reprints contact: service@oaepublish.com

How to cite this article: Barone M, Tenna S, Cogliandro A, Panasiti $\mathrm{V}$, Nobile C, Persichetti P. Application of regenerative medicine in treatment of acne scars. Plast Aesthet Res 2016;3:235-9.

Received: 02-06-2016; Accepted: 22-06-2016

(C) 2016 Plastic and Aesthetic Research | Published by OAE Publishing Inc. 


\section{INTRODUCTION}

Acne is a chronic inflammatory disease of the pilosebaceous unit, characterised by the presence of polymorphic skin lesions such as blackheads, papules, pustules, nodules and cysts. As regards the phatogenesis of the disease, some typical conditions such as a sebaceous hypersecretion and a hyper keratinisation of the follicular ostium, usually contribute to the creation of an anaerobic environment which facilitates the bacterial growth and the subsequent development of an inflammatory reaction (i.e. Propionibacterium acnes). Despite numerous topical and systemic therapeutic weapons, nowadays available to the dermatologist, some forms of acne, especially those characterised by an inflammation extended to deep dermis (nodular cysts), hesitate in scars, which strongly impact on both the aesthetic and, above all, on the psychological side of the disease. The scarring process is most often the result of a severe inflammatory process that extends to

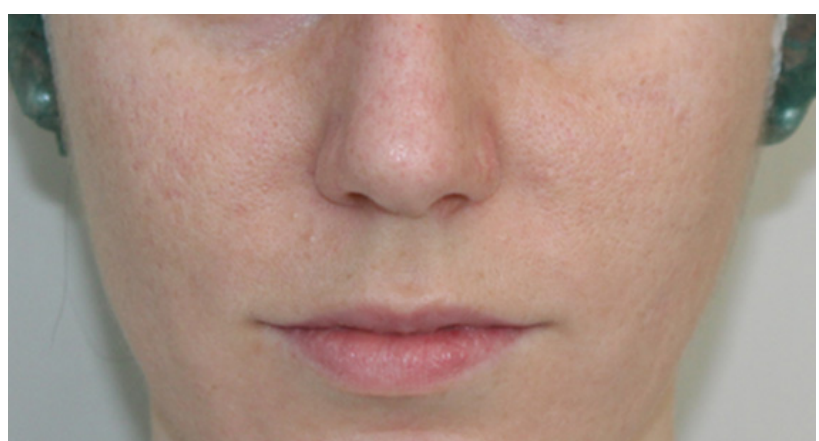

Figure 1: Icepick scar

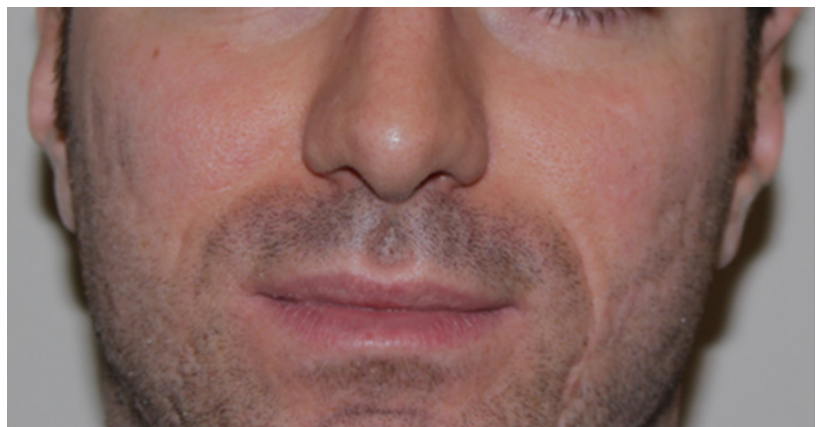

Figure 2: Rolling scar

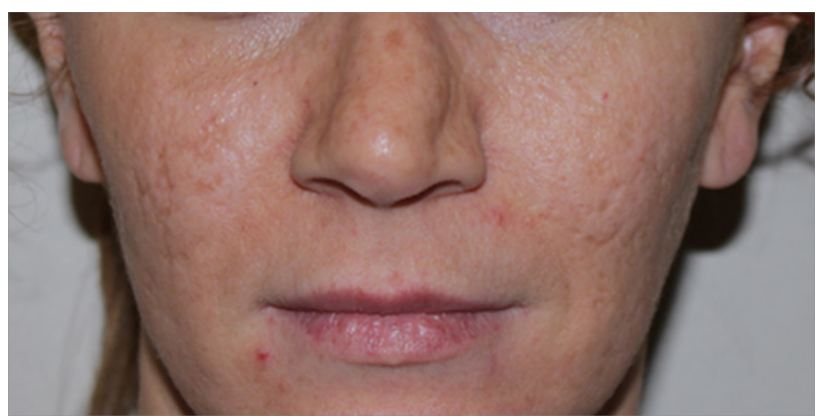

Figure 3: Boxcar scar the dermis as it usually happens in nodulocystic acne; however, it may also derive from the manipulation of less severe acne lesions by the patients themselves. Two forms of scar are generally identified: hypertrophic and atrophic, such as icepick [Figure 1], rolling [Figure 2] and the most common boxcar [Figure 3]. The management of acne scars consists of different approaches: physical approach (laser, pulsed light, cryotherapy), surgical approach (dermabrasion, punch excision etc.), fillers and chemical peels. ${ }^{[1]}$ Up to now, none of these methods has been considered the gold standard for the treatment of scars from acne and or is enough for a good cosmetic outcome; moreover, there are no studies in the literature analysing patient's satisfation after treatment. The aim of this study is to evaluate the efficacy of our protocol of nanofat and platelet-rich plasma (PRP) infiltration and fractional

Table 1: Thickness of subcutaneous tissue of the patients of group A

\begin{tabular}{lcccc}
\hline $\begin{array}{l}\text { ID of } \\
\text { patient }\end{array}$ & $\begin{array}{c}\text { I preoperative I postoperative II preoperative II postoperative } \\
\text { thick }(\mathbf{m m})\end{array}$ & thick $(\mathbf{m m})$ & thick $(\mathbf{m m})$ & thick (mm) \\
\hline 1 & 0.175 & 0.475 & 0.94 & 1.25 \\
2 & 0.11 & 0.61 & 0.685 & 0.950 \\
3 & 0.355 & 0.48 & 0.415 & 0.650 \\
4 & 0.175 & 0.61 & 0.550 & 0.750 \\
5 & 0.41 & 1.115 & 0.975 & 1.250 \\
6 & 0.52 & 0.69 & 1.09 & 1.150 \\
7 & 0.5 & 1.215 & 1.150 & 1.050 \\
8 & 0.35 & 1.32 & 1.02 & 1.550 \\
9 & 0.54 & 0.755 & 1.08 & 1.250 \\
10 & 1.09 & 1.92 & 1.750 & 1.950 \\
11 & 0.9 & 1.125 & 1.450 & 1.70 \\
12 & 0.615 & 0.750 & 0.650 & 0.850 \\
13 & 0.5 & 0.650 & 0.55 & 0.750 \\
14 & 1.3 & 1.550 & 1.450 & 1.650 \\
15 & 0.450 & 0.875 & 0.9 & 1.250 \\
\hline
\end{tabular}

I postoperative control: 3 months; II postoperative control: 3 months from the second treatment

Table 2: Thickness of subcutaneous tissue of the patients of group B

\begin{tabular}{|c|c|c|c|c|}
\hline $\begin{array}{l}\text { ID of } \\
\text { patient }\end{array}$ & $\begin{array}{l}\text { I preoperative } \\
\text { thick (mm) }\end{array}$ & $\begin{array}{l}\text { postoperative } \\
\text { thick (mm) }\end{array}$ & $\begin{array}{l}\text { Il preoperative } \\
\text { thick (mm) }\end{array}$ & $\begin{array}{l}\text { postoperative } \\
\text { thick (mm) }\end{array}$ \\
\hline 1 & 0.335 & 0.930 & 1.48 & 1.650 \\
\hline 2 & 0.36 & 0.450 & 0.445 & 0.550 \\
\hline 3 & 1.03 & 1.4 & 1.175 & 1.350 \\
\hline 4 & 0.98 & 1.3 & 1.275 & 1.650 \\
\hline 5 & 1.02 & 1.450 & 1.770 & 1.990 \\
\hline 6 & 0.545 & 0.760 & 0.880 & 1.3 \\
\hline 7 & 0.46 & 0.650 & 0.890 & 1.2 \\
\hline 8 & 0.9 & 0.9 & 1.1 & 1.240 \\
\hline 9 & 0.985 & 0.99 & 1.125 & 1.275 \\
\hline 10 & 0.350 & 0.780 & 0.880 & 0.9 \\
\hline 11 & 1.3 & 1.550 & 1.750 & 1.950 \\
\hline 12 & 0.7 & 0.920 & 1.150 & 1.370 \\
\hline 13 & 1.1 & 1.550 & 1.750 & 1.980 \\
\hline 14 & 0.450 & 0.880 & 0.9 & 1.2 \\
\hline 15 & 0.550 & 0.750 & 0.88 & 0.9 \\
\hline
\end{tabular}

I postoperative control: 3 months; II postoperative control: 3 months from the second treatment 
Table 3: Patient's quality of life evaluated with QoL-Q

\begin{tabular}{|c|c|c|c|}
\hline $\begin{array}{l}\text { Thinking about } \\
\text { the body part that } \\
\text { you turned to the } \\
\text { plastic surgeon: }\end{array}$ & $\begin{array}{c}\text { Preoperati } \\
(\%)^{*}\end{array}$ & $\begin{array}{l}\text { stoperatively } \\
(\%)^{*}\end{array}$ & $P$ \\
\hline $\begin{array}{l}\text { How do you feel in } \\
\text { your clothes? }\end{array}$ & $8(27)$ & $27(90)$ & $0.0001 \dagger$ \\
\hline $\begin{array}{l}\text { How you feel when } \\
\text { you're in the midst } \\
\text { of the people? }\end{array}$ & $5(17)$ & $28(93)$ & $0.0001 \dagger$ \\
\hline $\begin{array}{l}\text { How do you feel } \\
\text { showing the part of } \\
\text { the body? }\end{array}$ & $1(3)$ & $29(97)$ & $0.0001 \dagger$ \\
\hline $\begin{array}{l}\text { Do you feel safe in } \\
\text { working life? }\end{array}$ & $15(50)$ & $24(80)$ & $0.002 \dagger$ \\
\hline $\begin{array}{l}\text { Do you feel safe in } \\
\text { your private life? }\end{array}$ & $11(37)$ & $26(87)$ & 0.065 \\
\hline $\begin{array}{l}\text { Do you feel safe of } \\
\text { the body part for } \\
\text { which you have } \\
\text { addressed to the } \\
\text { plastic surgeon }\end{array}$ & $1(3)$ & $26(87)$ & $0.0001 \dagger$ \\
\hline $\begin{array}{l}\text { Do you feel safe of } \\
\text { your body? }\end{array}$ & $18(30)$ & $25(83)$ & 0.068 \\
\hline $\begin{array}{l}\text { Do you feel } \\
\text { reassured? }\end{array}$ & $7(23)$ & $25(83)$ & $0.0001 \dagger$ \\
\hline $\begin{array}{l}\text { Do you think your } \\
\text { quality of life is } \\
\text { good? }\end{array}$ & $13(43)$ & $24(80)$ & $0.003 \dagger$ \\
\hline $\begin{array}{l}\text { Do you think to be } \\
\text { successful in life? }\end{array}$ & $12(40)$ & $22(73)$ & $0.004 \dagger$ \\
\hline $\begin{array}{l}\text { You think your body } \\
\text { is beautiful? }\end{array}$ & $6(20)$ & $19(63)$ & $0.0001 \dagger$ \\
\hline
\end{tabular}

†: statistically significant; *: raw score $\geq 2$; QoL-Q: questionnaire of quality of life

$\mathrm{CO}_{2}$ laser resurfacing for face atrophic scars by acne and to analyse patient's satisfaction with our original questionnaire. All related patients are consented and agree with this publication.

\section{METHODS}

From March 2014 to June 2015, 30 patients with acne scars on the cheeks were selected for this pilot study. Age ranged between 18 and 52 years old. Patients were evaluated pre- and postoperatively by a physical examination, photographs and ultrasound scan with a 22 $\mathrm{MHz}$ probe to measure subcutaneous tissue thickness. All patients were treated by infiltration of nanofat and PRP. ${ }^{[2]}$ The production of PRP was achieved by RegenLab THT tube ${ }^{\circledR}$ method. ${ }^{[3,4]}$ Subsequently, patients were randomly divided into 2 groups: group $\mathrm{A}$, which also underwent a fractional $\mathrm{CO}_{2}$ laser resurfacing at $15 \mathrm{~W}$; and group $B$, which only underwent nanofat and PRP infiltration. Patients attended a 1 month, 3 months and 6 months follow-up after treatment. The difference in thickness obtained with the treatment in group A and in group B was compared through a $t$-test on unpaired data. Our original questionnaire of quality of life questionnaire (QoL-Q) was also administered pre- and postoperatively to analyse satisfaction and aesthetical perception of the result. The pre- and postoperative module was comprised of 11 multiple-response questions. The questionnaire was conceived by the authors as a test of self-administration, only for patients candidate to undergo all type of cosmetic procedures. Questionnaires were filled out in an anonymous fashion. Preoperative surveys were completed during the initial consultation, and postoperative surveys were completed at the 6 months postoperative visit. This was a cross-sectional study and therefore the patients who filled out preoperative surveys may be different from those who filled out postoperative surveys. Because surveys were filled out anonymously, there was no way to identify those patients who filled out both the preoperative and postoperative surveys. Statistical analysis was performed using descriptive and summary statistics to identify a central tendency. An unpaired $t$-test was performed to examine the significance of changes in mean scores of satisfaction. Fisher's exact test was used to detect any significant differences between preoperative and postoperative satisfaction for a dichotomous outcome. A value of $P<0.05$ was considered significant.

Inclusion criteria were: (1) patients from 18 to 40 years old in good health; and (2) patients with chronical acne scars on the cheeks.

Exclusion criteria were: (1) patients with diabetes, cancer, collagen disorders, deficiency status; (2) others acute or chronical dermatological disorders; (3) patients with coagulation defects and platelet count less than $150,000 / \mathrm{mm}^{3}$; (4) pregnancy status; (5) acute phase of acne; and (6) chronical assumption of anti-aggregants agents or non-steroidal anti-inflammatory drugs.

\section{RESULTS}

Preoperative thickness of subcutaneous tissue of patients from group A was $0.532 \mathrm{~mm}$, whilst preoperative thickness of subcutaneous tissue of patients from group $B$ was $0.737 \mathrm{~mm}$. Postoperative thickness of subcutaneous tissue was $1.201 \mathrm{~mm}$ in group A and $1.367 \mathrm{~mm}$ in group B. The improvement of thickness of subcutaneous tissue was $0.668 \mathrm{~mm}$ in group A and $0.630 \mathrm{~mm}$ in group B. Preoperative and postoperative thickness values of group A and group B are displayed in Tables 1 and 2 , respectively. The difference in thickness obtained with the treatment in group A and in group B was not statistically significant, with a $P=0.7289$. Answers of QoL-Q premodule and post-module questionnaires are reported in Table 3 and Figure 4, respectively.

\section{DISCUSSION}

Currently, we have many new treatments for acne scars, ${ }^{|48|}$ no gold standard has been officially identified yet. Historically, the most used treatments were: dermabrasion, a decade-old technique which employs the use of a motorised device equipped with an abrasive material to 


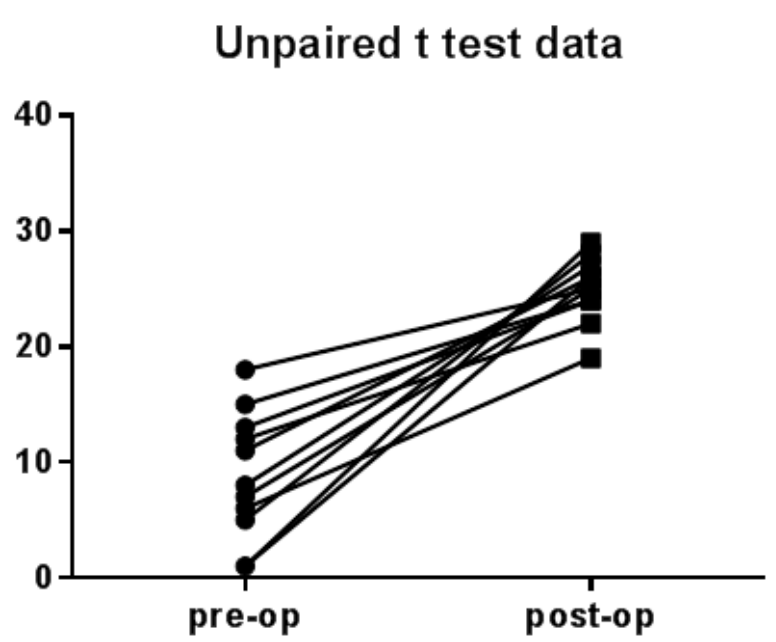

Figure 4: Student $t$-test for unpaired data. Pre-op: $8.818 \pm 1.661, n=$ 11; post-op: $25.00 \pm 0.8421, n=11 ; P<0.0001$

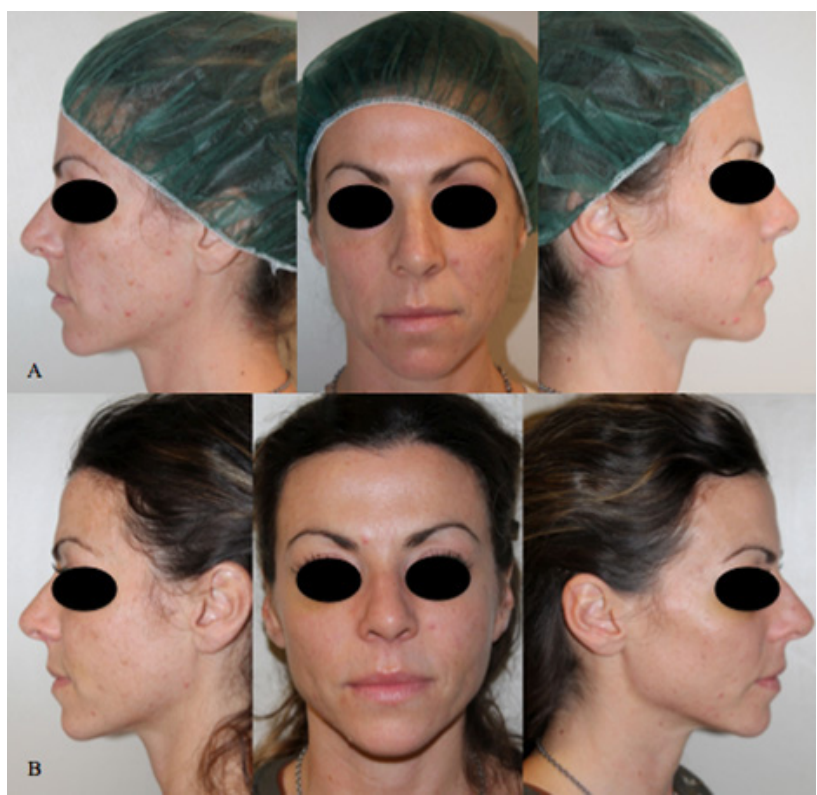

Figure 5: The case of a 33-year-old woman with icepick scar treated with platelet-rich plasma and nanofat injection and laser $\mathrm{CO}_{2}$. (A) preoperative situation; (B) 3 months after the second treatment

physically remove the superficial layers of the skin, thus inducing the wound-healing process with subsequent formation of new collagen; ${ }^{[9]}$ ablative lasers, which are effective in the treatment of atrophic scars; ${ }^{[10]}$ nonablative radiofrequency, which gives better results in the treatment of ice pick scars, compared to the use in more superficial scars; ${ }^{[11]}$ subcision, a more physically intensive technique useful for treatment of superficial atrophic acne scars; ${ }^{[12]}$ skin needling, also referred to as collagen induction therapy, which makes use of vertical needle punctures to treat rolling and boxcar scars; ${ }^{[13]}$ punch techniques, useful for treating deeper atrophic acne scarring, which are difficult to be treated otherwise ${ }^{[14]}$ chemical peels, which traditionally employ acidic compounds to strip away the outer layers of skin at variable depths, depending on the concentration of the agent being applied; ${ }^{[15]}$ soft-tissue

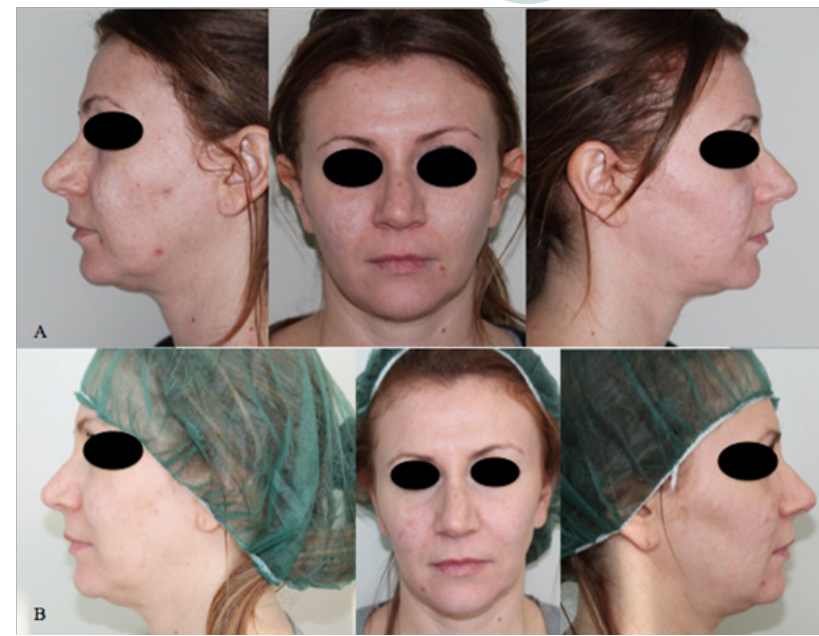

Figure 6: The case of a 36-year-old woman with boxcar acne scars, treated with platelet-rich plasma and nanofat injection and laser $\mathrm{CO}_{2}$. (A) preoperative situation; (B) 3 months after the second treatment

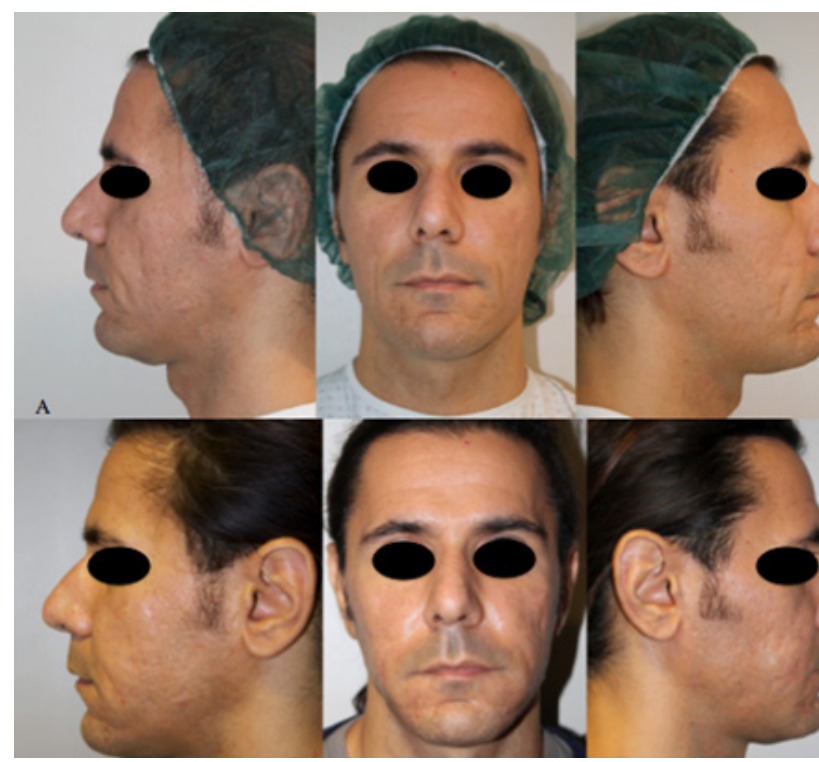

Figure 7: The case of a 41-year-old man with boxcar scars, treated with platelet-rich plasma and nanofat injection. (A) preoperative situation; (B) 3 months after the second treatment

augmentation, another effective treatment of superficial atrophic acne scars which is characterised by the injection of hyaluronic acid or calcium hydroxylapatite, poly-L-lactic acid, or even autologous fat to replace lost tissue volume while simultaneously inducing collagen production via stretching of dermal fibroblasts. ${ }^{[16]}$ The idea of our protocol came from the patients' request to search a satisfactory solution to the problem of atrophic scars of the face. These scars are not only the outcome of a devastating inflammatory disease for the patient's appearance, but in severe cases constitute the reason of relational and psychological problems. We think the atrophic acne scars should be treated as "dips" to fill and smooth. In fact, scars are found in the subcutaneous tissue, thus making a decisive surface treatment difficult to obtain. Scars need also a stimulation to maintain that volume. The best treatment is to fill the scars and 


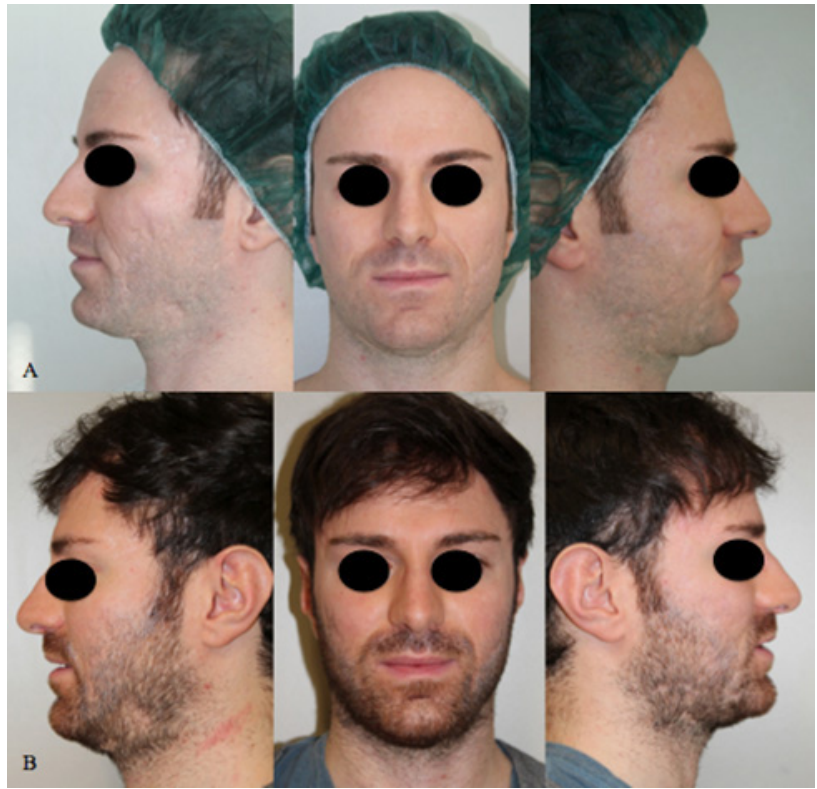

Figure 8: The case of a 28-year-old man with rolling scars treated with platelet-rich plasma and nanofat injection. (A) preoperative situation; (B) 3 months after the second treatment

stimulate the self-regeneration. The results obtained from the measurement of the thickness do not show evident differences in group $A$ [Figures 5 and 6 ] and in group $B$ [Figures 7 and 8], therefore the use of dermabrasion does not bring change in the aesthetic result. The surface treatment of atrophic scars is therefore not the best treatment to get good results. Into the 2 groups, we did not notice any difference between the various patients, nor according to the type of scars (icepick, boxcar or rolling), nor on the basis of the initial thickness of the scars. Indeed, we have calculated the differences of thicknesses obtained after treatment in group A and in group B and we applied a $t$-test for unpaired data with a non-significant result $(P$ $=0.7289$ ). All patients in both groups had a treatment benefit. Through our questionnaire we were able to know the patients' point of view, both before and after treatment and we could find in all a great improvement in the perception of its image. All patients were highly motivated to perform the treatment, both those with severe scars and those with milder scars. We report the results of the questionnaire into a single table because there was no difference between the 2 groups. The questionnaires which we administered to the patients were collected and processed in anonymous form so it was only possible to compare the responses obtained from each group of patients without being able to be divided into subgroups according to age, gender, type of scars. For the future, we would like to assess the stability of postoperative results with a longer follow-up and the effects of nano-fat plus PRP through hystological analysis (cutaneous biopsies during the treatment) on a short and long time. Also, we would like to use 2 other comparison groups, one with the use of only nanofat and 1 only with the use of PRP to study the role of the nanofat and the PRP in the treatment of atrophic scars.
In conclusion, combined approach with nanofat, PRP and $\mathrm{CO}_{2}$ laser seems to be effective to improve atrophic scars, however, infiltration alone proved to significantly increase skin and subcutaneous tissue thickness. QoL-Q confirmed the impact of acne scars on the face in social life and relationships. All patients, regardless of age, social class or educational level, are highly motivated to perform the treatment because they have not found a solution in previous treatments or have not performed any treatment yet.

\section{Financial support and sponsorship Nil.}

\section{Conflicts of interest}

There are no conflicts of interest.

\section{REFERENCES}

I. Basta-Juzbašić A. Current therapeutic approach to acne scars. Acta Dermatovenerol Croat 2010;18:17I-5.

2. Tonnard P, Verpaele A, Peeters G, Hamdi M, Cornelissen M, Declercq $\mathrm{H}$. Nanofat grafting: basic research and clinical applications. Plast Reconstr Surg 2013;132:1017-26.

3. Anitua E, Sánchez M, Orive G, Andía I. The potential impact of the preparation rich in growth factors (PRGF) in different medical fields. Biomaterials 2007;28:455 I-60.

4. Barrientos S, Stojadinovic O, Golinko MS, Brem H, Tomic-Canic M. Growth factors and cytokines in wound healing. Wound Repair Regen 2008; |6:585-60।.

5. Phothong W, Wanitphakdeedecha R, Sathaworawong A, Manuskiatti W. High versus moderate energy use of bipolar fractional radiofrequency in the treatment of acne scars: a split-face double-blinded randomized control trial pilot study. Lasers Med Sci 2016;31:229-34.

6. Zhou BR, Zhang T, Bin Jameel AA, Xu Y, Xu Y, Guo SL, Wang $Y$, Permatasari F, Luo D. The efficacy of conditioned media of adiposederived stem cells combined with ablative carbon dioxide fractional resurfacing for atrophic acne scars and skin rejuvenation. J Cosmet Laser Ther 2016; 18: 138-48.

7. Min S, Park SY, Yoon JY, Suh DH. Comparison of fractional microneedling radiofrequency and bipolar radiofrequency on acne and acnescar and investigation of mechanism: comparative randomized controlled clinical trial. Arch Dermatol Res 2015;307:897-904.

8. Seidel R, Moy RL. Improvement in atrophic acne scars using topical synthetic epidermal growth factor (EGF) serum: a pilot study. J Drugs Dermatol 2015; |4:1005-10.

9. Frank W. Therapeutic dermabrasion. Back to the future. Arch Dermatol 1994; 130: I 187-9.

10. Alster TS, West TB. Resurfacing of atrophic facial acne scars with a high-energy, pulsed carbon dioxide laser. Dermatol Surg 1996;22:I5I-4.

II. Ramesh M, Gopal M, Kumar S, Talwar A. Novel technology in the treatment of acne scars: the matrix-tunable radiofrequency technology J Cutan Aesthet Surg 2010;3:97-10I.

12. Alam M, Omura N, Kaminer MS. Subcision for acne scarring: technique and outcomes in 40 patients. Dermatol Surg 2005;31:310-7.

13. Fabbrocini G, Annunziata MC, D’Arco V, De Vita V, Lodi G, Mauriello MC, Pastore F, Monfrecola G. Acne scars: pathogenesis, classification and treatment. Dermatol Res Pract 2010;2010:893080.

14. Johnson WC. Treatment of pitted scars: punch transplant technique. Dermatol Surg Oncol 1986; I 2:260-5.

15. Lee JB, Chung WG, Kwahck H, Lee KH. Focal treatment of acne scars with trichloroacetic acid: chemical reconstruction of skin scars method. Dermatol Surg 2002;28:1017-21.

16. Wang F, Garza LA, Kang S, Varani J, Orringer JS, Fisher GJ, Voorhees JJ. In vivo stimulation of de novo collagen production caused by cross-linked hyaluronic acid dermal filler injections in photodamaged human skin. Arch Dermatol 2007; |43:155-63. 